\title{
Penerapan Pembelajaran Berbasis PAIKEM untuk Meningkatkan Aktivitas dan Hasil Belajar IPA pada Siswa Kelas VIII SMP Negeri 1 Tanjung Tahun Pelajaran 2011/2012
}

\author{
Dewa Made Suparwata \\ SMP Negeri 1 Tanjung, Lombok Utara, Indonesia \\ *Coresponding Author: dewamades@gmail.com
}

\begin{abstract}
Abstrak: Kurangnya pemahaman sisswa terhadap materi yang disampaikan oleh guru berakibat pada rendahnya hasil beljar IPA sisswa, salah satu penyebab dari masalah ini adalah kurang tepatnya pendekatan atau metode yang digunakan dalaam proses beljar mengajar IPA. Tujuan Penelitian ini adalah Mengetahui Penerapan Pembelajran Berbasis PAIKEM umtuk Meningkatkan Aktifitas dan Hasil Beljar IPA Sisswa Kelas VIII SMPN 1 Tanjung Tahun Pelajaran 2011/2012. Jenis penelitian ini merupakan Penelitian Tindakan Kelas (PTK) yang dilakukan dalaam dua siklus. Data aktifitas beljar sisswa diambil dangan menggunakan lembar observasi, sedangkan data hasil beljar sisswa diperoleh melalui tes yang diberikan pada tiap akhir siklus. Data hasil pengamatan dianalisis dangan menggunakan rumus persentase dan rumus ketuntasan klasikal. Hasil penelitian menunjukan bahwa aktifitas beljar sisswa pada siklus I sebesar 56\% tergolong dalaam kategori cukup aktif dan pada siklus II sebesar $88 \%$ tergolong dalaam kategori sangat aktif. Sedangkan data hasil beljar sisswa pada siklus I, dangan ketuntasan yang diperoleh sebesar 25\%, artinya bahwa belum tuntas dan pada siklus II memperoleh ketuntasan sebesar $86 \%$ dangan kategori tuntas. Berdasarkan hasil tersebut daapat disimpulkan bahwa penerapan pembelajran berbasis PAIKEM daapat meningkatkan aktifitas dan hasil beljar IPA pada sisswa kelas VIII SMPN 1 Tanjung Tahun Pelajaran 2011/2012.
\end{abstract}

Kata Kunci: PAIKEM; aktifitas belajar; hasil belajar IPA

\section{PENDAHULUAN}

Suatu pengajaran yang hanya mengutamakan prinsip individual tidak akan menguntungkan sisswa maupun masyarakat. Kehidupan sebagian besar sisswa dipengaruhi oleh orang lain maupun teman-temannya. Dimana ada orang hidup bersama-sama, tentu disana ada kontak social. Hubungan social antara sesama manusia merupakan suatu keharusan, sebab dangan kontak social orang akan daapat mengembangkan kepribadiannya dangan lebih sempurna. Dangan kegiatan-kegiatan ini maka dalaam setiap kegiatan mengajar guru dituntut agar sanggup menciptakan suasana social yang membangkitkan kerja sama diantara para sisswa dalaam mewujudkan materi pelajaran supaya daapat diserap lebih efektif dan efesien (Depdiknas, 2003).

Proses beljar mengajar pada intinya tertumpu pada suatu persoalan yaitu bagaimana guru melibatkan sisswa agar terjadi proses beljar yang efektif umtuk mencapai hasil sesuai dangan tujuan. Hal ini menuntut guru umtuk lebih kreatif memilih metode pembelajran yang sesuai dangan materi pelajaran yang akan disajikan kepada sisswa.

Pada proses pembelajran IPA selama ini guru lebih mendominasi proses pembelajran yaitu guru menyampaikan materi dangan metode ceramah sedangkan sisswa hanya mendengar, mencatat dan mengerjakan soal yang diberikan oleh guru. Pembelajran seperti ini akan mematikan kreatifitas sisswa sehingga berdampak pada rendahnya prestasi beljar sisswa. 
Informasi yang diperoleh dari hasil wawancara dangan guru IPA SMPN 1 Tanjung bahwa aktifitas sisswa dalaam mengikuti pelajaran masih rendah, walaupun ada sebagian kecil sisswa yang aktif dan menanggapi apa yang disampaikan oleh guru. Kegiatan pembelajran masih berpusat pada guru sehingga sisswa kurang memiliki kesempatan umtuk mengembangkan sendiri konsep-konsep IPA yang ada. Hal ini menyebabkan pelajaran IPA kurang menarik sehingga mengurangi antusias sisswa umtuk beljar IPA yang berdampak pada rendahnya prestasi beljar sisswa.

Tabel 1. Persentase Ketuntasan Beljar Sisswa Kelas VIII SMPN 1 Tanjung Tahun Pelajaran 2011/2012.

\begin{tabular}{|c|l|c|c|c|c|}
\hline No & Kelas & Jumlah sisswa & $\begin{array}{c}\text { Jumlah sisswa } \\
\text { yang tuntas } \\
\text { (Nilai } \geq 70)\end{array}$ & $\begin{array}{c}\text { Jumlah } \\
\text { sisswa yang } \\
\text { tidak tuntas } \\
\text { (Nilai } \leq 70)\end{array}$ & $\begin{array}{c}\text { Ketuntasan } \\
\text { klasikal }\end{array}$ \\
\hline 1 & VIII.1 & 34 & 26 & 8 & $74 \%$ \\
\hline 2 & VIII.2 & 35 & 22 & 13 & $62 \%$ \\
\hline 3 & VIII.3 & 36 & 25 & 11 & $69 \%$ \\
\hline 4 & VIII.4 & 36 & 17 & 19 & $47 \%$ \\
\hline
\end{tabular}

Dari data di atas diketahui bahwa ketuntasan beljar sisswa masih rendah, oleh karena itu perlu mendaapatkan perhatian yang serius. Umtuk itu dalaam penelitian tindakan kelas ini dicoba menerapkan model pembelajran berbasis PAIKEM dalaam rangka meningkatkan aktifitas dan hasil beljar IPA pada sisswa kelas VIII SMPN 1 Tanjung Tahun Pelajaran 2011/2012. PAIKEM sebagai upaya menciptakan sistem lingkungan beljar yang memberi peluang murid terlibat secara aktif (fisik, intelektual dan atau emosional).

Mengembangkan kreatifitas dan menyenangkan (menggairahkan umtuk beljar) serta daapat mewujudkan pembelajran (intrukionaldan pengiring) secara optimal. Seperti telah dikemukakan bahwa beljar itu pada perinsipnya selalu bermakna ada keaktifan, sehingga yang diupayakan dalaam PAIKEM adalah mengoptimalkan keaktifan murid itu.

Model pembelajran berbasis PAIKEM merupakan model pembelajran dangan sisswa beljar Aktif, Inovatif, Kreatif, Efektif dan Menyenangkan yang memiliki kemampuan heterogen. Model ini selalu mengusahakan agar sisswa teribat dalaam masalah-masalah yang dibahas selama pembelajran.

Berdasarkan uraian diatas, umtuk mengatasi permasalahan tersebut dalaam pembelajran IPA, peneliti bekerjasama dangan guru IPA kelas VIII.4 SMPN 1 Tanjung mencoba menerapkan Model Pembelajran Berbasis PAIKEM umtuk Meningkatkan Aktifitas dan Hasil Beljar IPA pada Sisswa Kelas VIII SMPN 1 Tanjung Tahun Pelajaran 2011/2012

\section{KAJIAN TEORI}

\section{Hakikat Belajar Biologi}

Umtuk memperoleh pengertian yang objektif tentang beljar terutama beljar disekolah, perlu dirumuskan secara jelas pengertian beljar. Pengertian beljar sudah banyak dikemukakan oleh para ahli psikologi pendidikan. Menurut Slameto (2010) bahwa beljar adalah suatu proses usaha yang dilakukan seseorang umtuk 
memperoleh suatu perubahan tingkah laku yang baru secara keseluruhan, sebagai hasil pengalamannya sendiri dalaam interaksi dangan lingkungannya.

Seperti diketahui bahwa biologi adalah salah satu disiplin ilmu yang merupakan cabang dari IPA, sehingga karakteristik IPA juga merupakan karakteristik biologi daapat ditandai sebagai berikut, (Slameto, 2003) :

a. Biologi merupakan kelompok ilmu pengetahuan yang terdiri dari fakta, konsep, prinsip, hukum dan teori tentang segala alam.

b. Biologi merupakan kegiatan keilmuan berupa pemikiran, penelitian, dan eksperimen melalui observasi daapat dipahami konsep biologi secara tepat.

c. Biologi selalu bersifat progresif dan komulatif, bersifat progresif maksudnya selalu berkembang maju ke arah yang lebih baik atau lebih sempurna, bersifat komulatif maksudnya setiap penemuan selalu berdasarkan pada penemuanpenemuan sebelumnya.

Berdasarkan karakteristik biologi di atas, maka biologi harus dipelajari atau dipahami melalui kegiatan empirik. Itulah sebabnya biologi merupakan ilmu yang lahir dan berkembang melalui langkah observasi, perumusan masalah, penyusunan hipotesis melalui eksperimen, kesimpulan dan penemuan materi atau konsep-konsep.

\section{Aktifitas Beljar}

Dalaam kegiatan beljar mengajar, guru sangat berperan dalaam aktifitas beljar sisswa karena aktifitas merupakan prinsip atau asas yang sangat penting dalaam interaksi beljar mengajar. Menurut Sardiman (2002), mengatakan bahwa yang lebih banyak melakukan aktifitas di dalaam pembentukan diri adalah anak itu sendiri, sedangkan guru memberikan bimbingan dan merencanakan segala kegiatan yang akan diperbuat oleh sisswa. Sedangkan menurut Slavin (2001), menjelaskan bahwa setiap orang yang ingin beljar harus aktif sendiri, tanpa adanya aktifitas maka proses beljar tidak mungkin terjadi.

Dari pendaapat di atas daapat disimpulkan bahwa dalaam kegiatan beljar, sisswa harus selalu aktif. Dangan kata lain bahwa dalaam beljar sangat diperlukan adanya aktifitas, tanpa adanya aktifitas proses beljar itu tidak mungkin berlangsung dangan baik.

Keaktifan beljar terdiri dari kata kreaktifitas dan kata beljar. "Keaktifan memiliki kata dasar aktif yang berarti giat dalaam beljar atau berusaha" (Arikunto, 2005). Keaktifan beljar berarti suatu usaha atau kerja yang dilakukan dangan giat dalaam beljar.

\section{Hasil Beljar}

Dalaam buku terbitan Depdiknas (2003) menyebutkan bahwa ciri-ciri hasil beljar adalah :

a) Adanya kemampuan sisswa umtuk mengingat kembali imformasi atau materi yang telah dipelajari,

b) Adanya kemampuan sisswa yang nampak dalaam keterampilan mengelompokkan, menyajikan dan menafsirkan data,

c) Adanya kemampuan sisswa umtuk menghasilkan suatu nilai dari materi pelajaran berdasarkan kriteria nyata, jelas dan obyektif,

Mencermati uraian tersebut maka ciri-ciri hasil beljar terwujud dalaam ranah kongitif, efektif, psikomotor serta kreaktifitas pada diri serta wajar tanpa tekanan orang lain. 


\section{Faktor-faktor yang Mempengaruhi Hasil Beljar}

Hasil beljar yang dicapai sisswa dipengaruhi oleh dua faktor utama yakni faktor dari dalaam diri sisswa dan faktor yang datang dari luar diri sisswa (Sudjana, 2011).

a) Faktor Intern

Adapun yang daapat digolongkan ke dalaam intern yaitu kecerdasan atau intelegensi, bakat, minat dan motivasi.

b) Faktor Ekstern

Faktor ekstern yang daapat mempengaruhi beljar adalah keadaan keluarga, keadaan sekolah dan keadaan lingkungan masyarakat.

Yang dimaksud dangan aktifitas dan hasil beljar dalaam penenelitian ini adalah hasil usaha beljar biologi berupa aspek kognitif yang diukur melalui soal ulangan. Tes menurut Arikunto ( 2010 ), merupakan serentetan pertanyaan atau latihan serta alat lain yang digunakan umtuk mengukur keterampilan, pengetahuan intelegensi, kemampuan atau bakat yang dimiliki oleh individu atau kelompok. Sedangkan soal adalah alat pengumpul informasi tertentu yang jika dibandingkan dangan alat-alat lain, soal lebih resmi karena penuh dangan batasan-batasan. Oleh karena itu, soal harus memenuhi aturan, persyaratan kelayakan dan pengambilan skor tertentu. Jadi soal merupakan penilaian akhir dari status masing-masing sisswa telah menyelesaikan sebagaian atau keseluruhan program pengajar.

\section{Metode Mengajar}

Metode merupakan suatu cara yang dipergunakan umtuk mencapai tujuan yang telah ditetapkan. Metode secara harfiah berarti cara. Dalaam pemakaian umum, metode diartikan sebagai suatu cara atau prosedur yang dipakai umtuk mencapai tujuan tertentu. Sedangkan kata mengajar berarti member pelajaran"(Mulyana, 2008).

Metode mengajar adalah cara penyajian bahan pelajaran kepada sisswa umtuk tercapainya tujuan yang telah ditetapkan (Santyasa, 2006). Definisi lain metode pembelajran menurut Slameto (2003), yaitu jalan atau tata cara yang harus dilalui umtuk mencapai suatu tujuan beljar yaitu umtuk mendaapatkan pengetahuan, sikap, kecakapan dan keterampilan.

Berdasarkan pendaapat di atas maka jelaslah pengertian metode pembelajran dalaam penelitian ini adalah cara yang dalaam fungsinya merupakan alat umtuk mencapai tujuan. Makin tepat metode yang digunakan, maka makin efektif pula perncapaian tujuan tersebut.

\section{Pendekatan Pembelajran PAIKEM.}

Pembelajran PAIKEM adalah pembelajran bermakna yang dikembangkan dangan cara membantu peserta didik membangun keterkaitan antara informasi (Pengetahuan) baru dangan pengalaman (Pengetahuan lain) yang telah dimiliki dan dikuasai peserta didik. Peserta didik dibeljarkan bagai mana mereka mempelajari konsep dan bagaimana konsep tersebut daapat dipergunakan diluar kelas. Peserta didik diperkenankann bekerja secara kooperatif (Suprijono, 2011).

PAIKEM sebagai upaya menciptakan sistem lingkungan beljar yang memberi peluang murid terlibat secara aktif (fisik, intelektual dan atau emosional).

Mengembangkan kreatifitas dan menyenangkan (menggairahkan umtuk beljar) serta daapat mewujudkan pembelajran (instruksional dan pengiring) secara optimal, 
Seperti telah dikmukakan bahwa beljar itu pada perinsipnya selalu bermakna ada keaktifan, sehingga yang diupayakan dalaam PAIKEM adalah mengoptimalkan keaktifan murid itu.

a) Aktif dimaksudkan bahwa dalaam proses pembelajran guru harus menciptakan suasana sedemikian rupa sehingga peserta didik aktif mengajukan pertanyaan, mengemukakan gagasan, dan mencari data dan informasi yang mereka perlukan umtuk memecahkan masalah.

b) Inovatif maksudnya bisa manghadaptasikan diri dari model pembelajran yang menyenangkan (learning is fun) yang merupakan kunci yang diterapkan dalaam pembelajran inovatif. .

c) Kreatif dimaksudkan agar guru menciptakan kegiatan beljar yang beragam, sehingga memenuhi berbagai tingkat kemampuan sisswa.

d) Efektif, yaitu menghasilkan apa yang harus dikuasai oleh sisswa setelah proses pembelajran berlangsung, sebab pembelajran memiliki sejumlah tujuan pembelajran yang harus dicapai. Jika pembelajran hanya aktif dan menyenangkan tetapi tidak efektif, maka pembelajran tersebut tidak ubahnya seperti bermain biasa.

e) Menyenangkan adalah suasana beljar mengajar yang menyenangkan sehingga siwa memusatkan perhatiannya secara penuh pada beljar sehingga waktu curah perhatiannya tinggi.

Jadi pembelajran PAIKEM adalah suatu metode pembelajran yang mampu melibatkan sisswa secara langsung dangan berbagai pengenalan terhadap lingkungan. Dangan demikian selama dalaam proses pembelajran akan mengajak sisswa lebih aktif, inovatif, kreatif, efektif dan menyenangkan.

\section{METODE PENELITIAN}

\section{Rancangan Penelitian}

Penelitian ini adalah penelitian tindakan kelas. Proses penelitian tindakan kelas dirancang dalaam bentuk siklus sesuai dangan rancangan yang ditetapkan dalaam PTK (Penelitian Tindakan Kelas). Dimana setiap siklus terdiri dari 4 (empat) tahap yaitu tahap perencanaan, tahap pelaksanaan tindakan, tahap observasi dan evaluasi, dan tahap refleksi (Arikunto, 2010).

Secara rinci prosedur tindakan tiap-tiap siklus dijabarkan sebagai berikut :

a. Perencanaan

Perencanaan kegiatan yang dilakukan dalaam pelaksanaan penerapan model

PAIKEM yaitu mempersiapkan hal-hal sebagai berikut :

1) Mensocialisasikan metode pembelajran PAIKEM pada peserta didik.

2) Menyiapkan skenario pembelajran menggunakan metode pembelajran PAIKEM.

3) Menyiapkan pedoman observasi umtuk mencatat kegiatan beljar sisswa dan kegiatan guru.

4) Membuat soal tes beljar dangan menggunakan lembar soal tes pilihan ganda.

b. Tahap Pelaksanaan

Kegiatan yang dilakukan pada tahap pelaksanaan tindakan ini yaitu: melaksanakan kegiatan beljar mengajar di kelas sesuai dangan skenario pembelajran yang telah disusun. Skenario pembelajran merupakan kegiatan guru 
dalaam merencanakan kegiatan pembelajran serta bagimana pelaksanaannya dalaam kelas apakah sesuai dangan perkembangan yang akan dicapai.

c. Tahap Observasi dan Evaluasi

Kegiatan pada tahap observasi adalah melakukan observasi secara kontinyu setiap kali berlangsungnya pelaksanaan tindakan dangan mengamati pelaksanaan kegiatan beljar mengajar, apakah sesuai dangan skenario pembelajran. Tahap evaluasi dilakukan setelah akhir setiap siklus dangan memberikan soal tes pilihan ganda umtuk mengetahui ketercapaian hasil beljar dangan menggunakan sistem beljar PAIKEM.

d. Tahap Refleksi

Refleksi dilakukan pada akhir siklus, pada tahap ini peneliti sebagai pengajar bersama guru yang bertindak sebagai observer mengkaji hasil yang diperoleh dari pemberian tindakan pada tiap siklus. Kegiatan pada tahap refleksi ini juga mengkaji kekurangan dan hambatan yang muncul pada saat berlangsungnya proses beljar mengajar. Sehingga diperoleh alternatif pemecahan masalah yang muncul pada setiap proses beljar mengajar sehingga daapat melakukan perbaikan umtuk pelaksanaan siklus selanjutnya. Hasil refleksi pada siklus I digunakan umtuk merencanakan tindakan pada siklus II dan hasil refleksi pada siklus II umtuk merencanakan tindakan pada siklus ketiga.

\section{Jenis Penelitian}

Jenis penelitian yang akan digunakan adalah penelitian tindakan kelas (Classroom Action Research) karena penelitian ini juga terlibat langsung dalaam proses beljar mengajar mulai dari awal sampai akhir pelajaran.

Penelitian tindakan kelas adalah suatu pencermatan terhadap kegiatan beljar berupa sebuah tindakan, yang sengaja dimunculkan dan terjadi dalaam sebuah kelas secara bersama (Arikunto, 2010). Adapun rancangan yang dimaksud adalah tindakan berupa Penerapan Pembelajran Berbasis PAIKEM Dalaam Upaya Meningkatkan Aktifitas dan Hasil Beljar IPA pada Sisswa Kelas VIII SMPN 1 Tanjung Tahun Pelajaran 2011/2012.

\section{Setting Penelitian}

Adapun yang akan menjadi subyek dalaam penelitian ini adalah Sisswa Kelas VIII SMPN 1 Tanjung Tahun Pelajaran 2011/2012. Penentuan subyek ini didasarkan atas ketuntasan klasikal yang terendah yaitu di kelas VIII 4 sebesar $47 \%$.

\section{Instrumen Penelitian}

Instrumen adalah alat ukur yang digunakan umtuk mengukur dalaam rangka pengumpulan data. Dalaam pendidikan, instrumen alat ukur yang digunakan umtuk mengumpulkan data daapat berupa tes maupun nontes (Purwanto, 2010 ).

Instrumen yang digunakan dalaam penelitian ini adalah :

1. Lembar observasi

Umtuk mengetahui proses pembelajran dangan penerapan pembelajran PAIKEM dan dilakukan pengamatan terhadap aktifitas beljar dan pengamatan terhadap keterlaksanaan pembelajran. Pengamatan dilakukan dangan mengamati kelas setiap siklus dan dibantu oleh satu orang guru yaitu guru IPA yang ada di tempat penelitian. Isi lembar observasi adalah berisi tentang daftar pertanyaan baik umtuk guru maupun umtuk sisswa. 
2. Soal tes

Soal tes diberikan pada akhir penyampaian materi, umtuk mengetahui hasil beljar sisswa. Tes dilakukan setiap akhir siklus beljar mengajar berlangsung dan pada akhir seluruh siklus. Jenis tes yang digunakan adalah tes obyektif atau pilihan ganda dan jumlah tes berjumlah 20 soal yang dikutip dari buku SMP/MTs kelas VIII.

\section{Teknik Pengumpulan Data}

Pengumpulan data dilakukan guna mendaapatkan data yang tepat dan akurat yang sesuai dangan kebutuhan peneliti yang tepat dalaam penelitian ini. Pada penelitian ini teknik pengumpulan data yang digunakan adalah :

1. Tes

Tes adalah serentetan pertanyaan atau latihan yang digunakan umtuk mengukur keterampilan, dan pengetahuan intelegensi yang dimiliki oleh individu atau kelompok (Arikunto, 2010 ). Tes ini digunakan umtuk mengetahui tingkat pemahaman dalaam mengetahui materi yang disampaikan (hasil beljar).

2. Observasi

Observasi merupakan teknik pengumpulan data dangan cara mengamati setiap kejadian yang sedang berlangsung dan mencatatnya dangan alat observasi tentang hal-hal yang akan diamati atau diteliti (Sanjaya, 2009). Data tentang keterlaksanaan KBM (Kegiatan Beljar Mengajar) diperoleh melalui observasi.

\section{Teknik Analisis Data}

\section{Lembar Observasi Aktifitas Beljar}

Data mengenai ketercapaian Sistem Beljar PAIKEM dalaam meningkatkan aktifitas dan hasil beljar biologi yang berupa kata-kata kualitatif selanjutnya disajikan dalaam bentuk kuantitatif agar daapat dianalisis secara persen yang dimaksud :

$P=\frac{\sum X}{n} x 100 \%$ (Arikunto, 2008)

Keterangan :

$\mathrm{P}=$ Persentase aktifitas beljar sisswa

$\sum X \quad=$ Skor yang diperoleh

$n \quad=$ Skor maksimal

Tabel 2. Kategori Aktifitas Beljar Sisswa Kelas VIII

\begin{tabular}{|c|c|c|}
\hline No. & Persentase & Kategori \\
\hline 1. & $80-100 \%$ & Sangat Aktif \\
\hline 2. & $69-79 \%$ & Aktif \\
\hline 3. & $40-59 \%$ & Cukup Aktif \\
\hline 4. & $20-39 \%$ & Kurang Aktif \\
\hline 5. & $0-19 \%$ & Pasif \\
\hline
\end{tabular}

Sumber: (Arikunto dalaam Purwakanti 2010)

2. Hasil Beljar Sisswa

@ 2020 DIKSI (https://jurnal.bimaberilmu.com/index.php/diksi) 
Setelah memperoleh data hasil beljar sisswa, maka data tersebut kemudian dianalisis secara kuantitatif.

a. Ketuntasan Individu

Setiap sisswa dalaam proses beljar mengajar dikatakan tuntas terhadap materi pembelajran yang diberikan apabila memperoleh nilai $\geq 70$ sesuai dangan KKM di sekolah tersebut.

Umtuk mengetahui kekuntasan individu, maka dianalisis dangan menggunakan rumus sebagai berikut :

Keterangan :

$$
\mathrm{N}=\frac{\mathrm{T}}{\mathrm{Tt}} \times 100
$$

$$
\begin{aligned}
& \mathrm{N}=\text { Nilai sisswa } \\
& \mathrm{T}=\text { Skor yang diperoleh sisswa } \\
& \mathrm{Tt}=\text { Jumlah total skor } \\
& 100=\text { Skala nilai }
\end{aligned}
$$

(Purwanto dalaam Purwakanti, 2010)

\section{b. Ketuntasan Klasikal}

Umtuk mengetahui ketuntasan sisswa secara klasikal dianalisis dangan menggunakan rumus :

$K K=\frac{X}{Z} x 100 \% \quad$ (Arikunto dalaam Purwakanti, 2010)

Keterangan :

$K K=$ Ketuntasan Klasikal

$X=$ Jumlah sisswa yang memperoleh nilai $\geq 70$

$Z$ = Jumlah seluruh sisswa

Suatu kelas dikatakan tuntas beljarnya jika di kelas tersebut terdaapat $\geq$ 85\% sisswa telah mencapai ketuntasan individual, umtuk mengetahui kondisi ini, maka perlu dicari inovasi pembelajran yang dirasakan cocok umtuk merealisasikan tuntutan KTSP. Karena menurut (Sudjana, 2002), media pembelajran daapat mempertinggi proses beljar sisswa yang dicapai sesuai dangan standar nilai yang ditetapkan dalaam Musyawarah Guru Mata Pelajaran (MGMP) oleh sekolah umtuk mencapai tujuan tersebut.

\section{HASIL DAN PEMBAHASAN}

\section{Hasil Penelitian}

Penelitian ini dilaksanakan pada bulan Januari 2012 pada sisswa kelas VIII.4 yang terdiri dari 36 sisswa, dan dilaksanakan melalui dua siklus. Dari hasil penelitian yang dilaksanakan umtuk setiap siklus diperoleh berbagai data kualitatif dan kuantitatif hasil penelitian yang telah dilakukan dan diuraikan hasilnya sebagai berikut :

a. Observasi Aktifitas Beljar Mengajar

Tabel 3. Data Hasil Aktifitas Sisswa Kelas VIII.4 Siklus I dan Siklus II di SMPN 1 Tanjung Tahun Pelajaran 2011/2012.

\begin{tabular}{|l|l|l}
\hline No & Indikator & Skor \\
\hline
\end{tabular}




\begin{tabular}{|c|c|c|c|}
\hline & & Siklus I & Siklus II \\
\hline 1 & 1 & 3 & 5 \\
\hline 2 & 2 & 3 & 4 \\
\hline 3 & 3 & 3 & 5 \\
\hline 4 & 4 & 2 & 3 \\
\hline 5 & 5 & 3 & 5 \\
\hline Total skor & 14 & 22 \\
\hline Persentase & $56 \%$ & $88 \%$ \\
\hline Kategori & Cukup aktif & Sangat Aktif \\
\hline
\end{tabular}

Tabel 3. Aktifitas Kegiatan Beljar Mengajar Guru Siklus I dan Siklu II di SMPN 1 Tanjung Tahun Pelajaran 2011/2012.

\begin{tabular}{|l|c|c|}
\hline \multirow{2}{*}{\multicolumn{1}{|c|}{ Aspek yang di observasi }} & \multicolumn{2}{c|}{ Hasil } \\
\cline { 2 - 3 } & Siklus I & Siklus II \\
\hline $\begin{array}{l}\text { 12 Aspek yang di teliti dari setiap } \\
\text { siklus yang Nampak }\end{array}$ & 9 & 12 \\
\hline Total skor & 9 & 12 \\
\hline Persentase & $75 \%$ & $100 \%$ \\
\hline Kategori & Baik & Sangat Baik \\
\hline
\end{tabular}

b. Hasil Refleksi

Tabel 4. Tabel Hasil Refleksi Pelaksanaan Tindakan Pada Siklus I Serta Perbaikan Pada Siklus II.

\begin{tabular}{|c|c|c|}
\hline No & Tindakan pada siklus I & Perbaikan pada siklus II \\
\hline 1 & $\begin{array}{l}\text { Sisswa kurang memperhatikan } \\
\text { dangan seksama selama proses } \\
\text { beljar mengajar berlangsung }\end{array}$ & $\begin{array}{l}\text { Guru mengarahkan sisswa agar lebih } \\
\text { memperhatikan dangan seksama selama } \\
\text { proses beljar mengajar berlangsung }\end{array}$ \\
\hline 2 & $\begin{array}{l}\text { Sisswa kurang memiliki } \\
\text { tanggung jawab terhadap } \\
\text { kelompoknya }\end{array}$ & $\begin{array}{l}\text { Guru harus menegaskan arti pentingnya } \\
\text { pembagian tugas dalaam masing-masing } \\
\text { anggota agar semua anggota daapat } \\
\text { memiliki rasa tanggung jawab yang sama } \\
\text { terhadap kelompoknya }\end{array}$ \\
\hline 3 & $\begin{array}{l}\text { Sisswa tidak mengemukakan } \\
\text { pendaapatnya terhadap } \\
\text { kelompok sendiri }\end{array}$ & $\begin{array}{l}\text { Guru harus aktif mendampingi sisswa dan } \\
\text { memfasilitas kegiatan kelompok yang } \\
\text { masih kurang pemahamannya }\end{array}$ \\
\hline 4 & $\begin{array}{l}\text { Sisswa tidak mengajukan } \\
\text { pertanyaan terhadap hal-hal } \\
\text { yang belum jelas }\end{array}$ & $\begin{array}{l}\text { Guru harus bisa mengaitkan materi } \\
\text { sebelumnya dangan materi yang akan } \\
\text { diajarkan }\end{array}$ \\
\hline 5 & $\begin{array}{l}\text { Siwa tidak berusaha umtuk } \\
\text { menjawab pertanyaan yang } \\
\text { diajukan oleh guru }\end{array}$ & $\begin{array}{l}\text { Guru harus mampu membangun } \\
\text { komunikasi yang interaktif dangan sisswa } \\
\text { dalaam proses pembelajran }\end{array}$ \\
\hline 6 & $\begin{array}{l}\text { Sisswa tidak berani } \\
\text { mengemukakan pendaapat } \\
\text { terhadap guru }\end{array}$ & $\begin{array}{l}\text { Guru harus bisa memotivasi dan member } \\
\text { dorongan serta semangatkepada sisswa } \\
\text { umtuk tidak malu bertanya }\end{array}$ \\
\hline
\end{tabular}




\begin{tabular}{|c|l|l|}
\hline 7 & $\begin{array}{l}\text { Sisswa melakukan pekerjaan } \\
\text { lain }\end{array}$ & $\begin{array}{l}\text { Guru meminta sisswa umtuk lebih } \\
\text { memperhatikan pelajaran }\end{array}$ \\
\hline 8 & $\begin{array}{l}\text { Sisswa belum mampu } \\
\text { mengambil dan mencatat } \\
\text { sendiri apa yang di diskusikan } \\
\text { dalaam beljar kolaboratif } \\
\text { sistem PAIKEM }\end{array}$ & $\begin{array}{l}\text { Guru mengarahkan sisswa umtuk } \\
\text { menambah kesimpulan }\end{array}$ \\
\hline 9 & $\begin{array}{l}\text { Sisswa tidak menanggapi } \\
\text { pendaapat yang diterimanya }\end{array}$ & $\begin{array}{l}\text { Guru mengarahkan sisswa agar berani } \\
\text { mengemukakan pendaapat }\end{array}$ \\
\hline 10 & $\begin{array}{l}\text { Sisswa tidak membuat } \\
\text { rangkuman yang diberikan oleh } \\
\text { guru }\end{array}$ & $\begin{array}{l}\text { Guru meminta sisswa umtuk membuat } \\
\text { rangkuman. }\end{array}$ \\
\hline 11 & $\begin{array}{l}\text { Hasil evaluasi beljar sisswa } \\
\text { belum mencapai ketuntasan }\end{array}$ & $\begin{array}{l}\text { Guru berupaya memaksimalkan kegiatan } \\
\text { pembelajran dikelas }\end{array}$ \\
\hline 12 & $\begin{array}{l}\text { Guru tidak menyampaikan } \\
\text { tujuan materi pembelajran di } \\
\text { kelas }\end{array}$ & $\begin{array}{l}\text { Guru menyampaikan tujuan materi } \\
\text { pembelajran dikelas }\end{array}$ \\
\hline 13 & $\begin{array}{l}\text { Guru tidak mengkaitkan materi } \\
\text { pelajaran yang akan dibahas } \\
\text { dangan materi pembelajran }\end{array}$ & $\begin{array}{l}\text { Guru mengkaitkan materi pelajaran yang akan } \\
\text { dibahas dangan materi pembelajran }\end{array}$ \\
\hline 14 & $\begin{array}{l}\text { Guru tidak memberi informasi } \\
\text { kepada sisswa selanjutnya } \\
\text { melakukan refleksi terhadap } \\
\text { materi yang disampaikan }\end{array}$ & $\begin{array}{l}\text { Guru memberi informasi kepada sisswa } \\
\text { selanjutnya melakukan refleksi terhadap materi } \\
\text { yang disampaikan }\end{array}$ \\
\hline
\end{tabular}

c. Hasil Evaluasi Beljar Sisswa

Tabel 5. Hasil Evaluasi Beljar Sisswa Kelas VIII.4 Siklus I dan Siklus II di SMPN 1 Tanjung Tahun Pelajaran 2010/2011.

\begin{tabular}{|c|l|c|c|}
\hline No & \multicolumn{1}{|c|}{ Aspek } & Siklus I & Siklus II \\
\hline 1 & Jumlah sisswa keseluruhan & 36 & 36 \\
\hline 2 & Jumlah sisswa yang ikut tes & 36 & 36 \\
\hline 3 & Jumlah sisswa yang tuntas & 9 & 31 \\
\hline 4 & Jumlah sisswa yang tidak tuntas & 27 & 5 \\
\hline 5 & Nilai rata-rata kelas & $55 \%$ & $77 \%$ \\
\hline 6 & $\begin{array}{l}\text { Persentase ketuntasan klasikal } \\
(\%)\end{array}$ & $25 \%$ & $86 \%$ \\
\hline
\end{tabular}

\section{Pembahasan}

Penelitian Tindakan Kelas ini dilakukan dalaam dua siklus dangan menggunakan pendekatan beljar PAIKEM pada pokok bahasan Sistem Pencernaan Pada Manusia. Penelitian ini menggunakan prosedur Penelitian Tindakan Kelas (PTK) yang telah ditetapkan yaitu tahap perencanaan, pelaksanaan tindakan, observasi dan refleksi. Pada siklus I tahap perencanaan dilakukan persiapanpersiapan umtuk melakukan pembelajran seperti membuat Rencana Pelaksanaan Pembelajran (RPP) menyiapkan lembar observasi dan membuat alat evaluasi. Penelitian Tindakan Kelas ini kemudian dilanjutkan pada tahap tindakan dilakukan 
pada dua siklus. Adapun langkah-langkah pembelajran tertuang dalaam skenario pembelajran.

\section{Hasil Aktifitas Beljar Sisswa}

Dalaam kegiatan beljar mengajar, guru sangat berperan dalaam aktifitas beljar sisswa karena aktifitas merupakan prinsip atau asas yang sangat penting dalaam interaksi beljar mengajar. Menurut Sardiman (2002), mengatakan bahwa yang lebih banyak melakukan aktifitas di dalaam pembentukan diri adalah anak itu sendiri, sedangkan guru memberikan bimbingan dan merencanakan segala kegiatan yang akan diperbuat oleh sisswa. Sedangkan menurut Slavin (2001), menjelaskan bahwa setiap orang yang ingin beljar harus aktif sendiri, tanpa adanya aktifitas maka proses beljar tidak mungkin terjadi.

Dangan menerapkan pembelajran model PAIKEM aktifitas sisswa daapat meningkat, karena beljar menggunakan PAIKEM adalah suatu metode beljar yang menekankan bahwa interaksi dangan orang lain umtuk memecahkan berbagai kesulitan dalaam beljar adalah bagian terpenting dalaam meningkatkan aktifitas dan hasil beljar sisswa. Berdasarkan hasil analisis data aktifitas beljar sisswa pada siklus I tergolong cukup aktif dangan skor 14 dangan persentase keaktifan 56\% ini tergolong dalaam kategori cukup aktif. Sedangkan pada siklus II terdaapat peningkatan aktifitas dangan skor 22 persentase keaktifan $88 \%$. Peningkatan aktifitas sisswa dari siklus I ke siklus II juga disebabkan karena metode yang dipakai dalaam pembelajran yaitu dangan beljar sistem PAIKEM yang daapat memudahkan sisswa umtuk mengomunikasikan gagasan-gagasannya, serta interaksi dalaam beljar yang terjadi antara guru dan sisswa sangat aktif.

Dangan menerapkan model pembelajran PAIKEM aktifitas beljar sisswa daapat meningkat, karena beljar menggunakan model PAIKEM adalah suatu metode beljar yang menekankan bahwa interaksi dangan orang lain umtuk memecahkan berbagai kesulitan dalaam beljar adalah bagian terpenting dalaam meningkatkan aktifitas dan hasil beljar sisswa.

\section{Hasil Aktifitas Beljar Mengajar Guru}

Berdasarkan hasil analisis data aktifitas beljar mengajar guru pada siklus I dangan total skor 9 dangan persentase keaktifan $75 \%$ ini tergolong dalaam kategori aktif. Hal ini terjadi karena beberapa hal diantaranya yaitu guru tidak menyampaikan tujuan materi pelajaran dikelas, guru tidak mengkaitkan materi pelajaran yang akan dibahas dangan materi pembelajran dan guru tidak memberi informasi kepada sisswa selanjutnya melakukan repleksi terhadap materi yang disampaikan, sehingga perlu dilakukan refleksi pada siklus II.

Adapun tindakan yang dilakukan pada siklus II prinsipnya sama pada siklus sebelumnya. Namun pada siklus II dilakukan refleksi terhadap kekurangankekurangan pada siklus I diantaranya guru menyampaikan tujuan pembelajran, guru mengaitkan materi pelajaran yang akan dibahas dangan materi pembelajran dan guru memberi informasi kepada sisswa selanjutnya melakukan repleksi terhadap materi yang disampaikan.

Setelah refleksi dilakukan ternyata hasil aktifitas beljar guru pada siklus II mengalami peningkatan aktifitas dangan total skor 12 dangan persentase keaktifan $100 \%$. Hal ini di karenakan langkah-langkah penerapan strategi pembelajran PAIKEM berjalan dangan baik sehingga mendaapatkan hasil yang maksimal. 


\section{Hasil Evaluasi Beljar Sisswa}

Setelah proses beljar mengajar menggunakan metode pendekatan sistem pembelajran PAIKEM ternyata hasil evaluasi pada siklus I menunjukan persentase ketuntasan $25 \%$. Secara klasikal ketuntasan beljar sisswa pada siklus I belum tuntas karena pencapaian hasil ketuntasan beljar kurang dari $85 \%$. Hal tersebut disebabkan karena sisswa masih belum terbiasa dangan model pembelajran yang digunakan, sisswa kurang memperhatikan pelajaran dangan seksama, sisswa belum memiliki tanggung jawab dalaam kelompoknya, sisswa tidak berani umtuk mengajukan pertanyaan kepada gurunya berkaitan dangan materi pelajaran yang belum jelas, sisswa tidak menanggapi setiap pertanyaan yang diberikan oleh guru dan sisswa tidak membuat rangkuman yang diberikan oleh guru. Berdasarkan dari hasil siklus I maka dilakukan penyempurnaan pada siklus II dangan cara memperbaiki kekurangan pada siklus I.

Adapun tindakan yang dilakukan pada siklus II pada prinsipnya sama dangan siklus sebelumnya. Berdasarkan dari hasil siklus I maka dilakukan penyempurnaan pada siklus II dangan cara memperbaiki kekurangan-kekurangan pada siklus I yaitu antara lain dangan cara meminta sisswa umtuk lebih serius dan memperhatikan pelajaran dangan seksama agar sisswa daapat mencapai hasil yang lebih maksimal dan sisswa sudah mulai terbiasa dangan model pembelajran yang digunkan.

Setelah refleksi pada siklus II sisswa memperoleh hasil yang lebih baik. Ini ditunjukkan dari hasil evaluasi siklus II dimana persentase ketuntasan klasikalnya sebesar 86\% yang berarti hasil beljar sisswa telah tuntas.

Keuntungan dari penerapan model pembelajran PAIKEM yaitu guru lebih mudah menarik minat serta semangat beljar sisswa karena sisswa lebih senang berinteraksi langsung dangan sisswa dan guru itu sendiri dalaam beljar di dalaam kelas. Dari proses tindakan dan hasil yang diperoleh pada siklus I dan siklus II, menunjukkan hasil yang sangat bagus. Berarti penerapan pembelajran model PAIKEM daapat meningkatkan aktifitas dan hasil beljar sisswa khususnya pada pelajaran IPA biologi.

\section{KESIMPULAN}

Berdasarkan hasil penelitian yang diperoleh, daapat disimpulkan bahwa penerapan pembelajran berbasis PAIKEM daapat meningkatkan aktifitas dan hasil beljar IPA pada sisswa kelas VIII SMPN 1 Tanjung Tahun Pelajaran 2011/2012. Hal ini daapat dilihat dari aktifitas kegiatan beljar mengajar guru pada siklus I dangan persentase $75 \%$ masuk dalaam kategori baik dan pada siklus II dangan persentase $100 \%$ masuk dalaam kategori sangat baik. Sedangkan data hasil aktifitas sisswa pada siklus I dangan persentse $56 \%$ masuk dalaam kategori cukup aktif dan pada siklus II dangan persentase $88 \%$ dangan kategori sangat aktif. Dari hasil evaluasi beljar sisswa pada siklus I dangan persentase ketuntasan klasikal $25 \%$ dan ada peningkatan pada siklus II dangan persentase ketuntasan klasikal $86 \%$.

Saran dan tindak lanjut dari hasil penilitian ini antara lain: 1) Dalaam proses beljar mengajar hendaknya menggunakan metode sesuai dangan materi yang akan disampaikan agar sisswa tidak cepat merasa bosan dalaam mengikuti pelajaran; 2) Hasil penelitian ini diharapkan daapat digunakan sebagai bahan pertimbangan bagi guru dalaam upaya meningkatkan hasil beljar sisswa khususnya pada pokok bahasan 
sistem pencernaan pada manusia dan mata pelajaran biologi pada umumnya; dan 3) Bagi peneliti selanjutnya yang ingin melanjutkan penelitian tentang PAIKEM diharapkan agar daapat menerapkan model pembelajran ini pada pokok bahasan atau mata pelajaran yang lain dan juga hendaknya daapat mempertimbangkan serta memperhitungkan faktor-faktor lain yang kemungkinan daapat mempengaruhi hasil peneliti sehingga kekurangan-kekurangan yang ada pada peneliti ini daapat disempurnakan.

\section{DAFTAR PUSTAKA}

Anom, DK. (2011). Meningkatkan Prestasi Beljar IPA dangan Pendekatan Paikem Pada Kelas V SD Negeri 4 Mambalan Tahun Pelajaran 2010/2011. Universitas Mataram.

Arikunto. (2005). Dasar-Dasar Evaluasi Pendidikan. Jakarta : Bumi Aksara.

Arikunto. (2008). Penelitian Tindakan Kelas. Jakarta : Bumi Aksara.

Arikunto. (2010), Prosedur Penelitian Suatu Pendekatan Praktik Edis Revisi. Jakarta: Rineka Cipta

Depdiknas. (2003). Dasar-Dasar Evaluasi Pendidikan. Jakarta : Bumi Aksara

Hamalik. (2004). Fsikologi Beljar Mengajar. Bandung : Sinar Baru Grasindo.

Hamzah. (2002). Metodologi Pembelajran di Kelas. Bandung : Sinar Baru

Mulyana. (2008). Metodologi Penelitian Kualitatif. Bandung : Remaja Rosda Karya.

Nasir, (1999). Penelitian Tindakan Kelas. Jakarta : Rineka Cipta.

Purwakanti. (2010). Penerapan Model Pembelajran Kolaboratif MURDER Dalaam Meningkatkan Aktifitas Beljar Dan Hasil Beljar Biologi Slameto, 2003. Beljar dan Faktor-faktor Yang Mempengaruhinya. Jakarta : Rineka Cipta.

Purwanto. (2010). Evaluasi Hasi Beljar. Yogyakarta : Pustaka Pelajar

Sanjaya. (2009). Penelitian dan Penilaian Pendidikan. Jakarta : Sinar Baru

Sawiji, Dkk. (2011). Prestasi. Jakarta : Prestasi Agung Pratama.

Santyasa, (2006). Metodologi Penelitian Tindakan Kelas. Singaraja: Universitas PendididkanGanesha. (UG press).

Sardiman, (2002). Konsep dan Makna Pembelajran. Bandung : Alfabeta

Slameto. (2003). Beljar dan Faktor-Faktor Yang Mempengaruhinya. Jakarta: Asdi Mahasatya.

Slameto. (2010). Beljar dan Faktor-Faktor Yang Mempengaruhinya. Jakarta: Rineke Cipta.

Slavin, TG. (2001). Action research : Collecting and analyzing data. http://www.nipissngu.ca.oar/Reports/reports and document - Thomas G Ryan\%20.pdf 
Sudjana. (2002). Dasar-Dasar Proses Beljar Mengajar. Bandung: Sinar Baru Algesindo.

Sudjana. (2011). Dasar-Dasar Proses Beljar Mengajar. Bandung: Sinar Baru Algesindo.

Suprijono, A. (2011). Cooperative Learning. Yogyakarta : Pustaka Beljar.

Suryabrata, S. (2004). Metodologi Penelitian. Jakarta: Raja Grapindo Prasada

Syarifuddin, S. (2019). IDENTIFIKASI KESULITAN REPRESENTASI MATEMATIS SISWA SMP PADA PEMECAHAN MASALAH PECAHAN. SUPERMAT (Jurnal Pendidikan Matematika), 3(1), 34-42.

Syarifuddin, S. (2018). Pengaruh Pembelajaran Kooperatif Tipe Jigsaw Dan Tipe Group Investigation (GI) Terhadap Ketercapaian Kompetensi Dan Kemampuan Komunikasi Matematika Siswa Di SMA. Jurnal Ilmiah Mandala Education, 4(1), 163-172 